\title{
Autologous transplantation of mononuclear bone marrow cells in patients with chronic myocardial infarction*
}

\author{
Jaroslav Meluzín, Stanislav Janoušek*, Jiří Mayer**, Ladislav Groch, \\ Jan Sitar, Miloslav Tejc, Petr Kala*, Roman Panovský, Milan Kamínek***, \\ Martin Klabusay***, Zdeněk Kořístek***, Ladislav Dušek ${ }^{* * * *}$ \\ 1st Department of Internal Medicine/Cardioangiology, St. Anna Hospital, \\ *Department of Internal Medicine/Cardiology. \\ **Department of Internal Medicine/Hematooncology, Masaryk University, Brno, \\ ***Department of Nuclear Medicine, Olomouc Teaching Hospital, Olomouc, \\ ${ }^{* * * *}$ Center of Biostatistics and Analyses, Masaryk University, Brno, Czech Republic
}

\begin{abstract}
Meluzín J, Janoušek S*, Mayer J**, Groch L, Sitar J, Tejc M, Kala P*, Panovský R, Kamínek M***, Klabusay M***, Kořístek $Z^{* * *}$, Dušek L**** (1st Department of Internal Medicine/Cardioangiology, St. Anna Hospital, *Department of Internal Medicine/Cardiology, **Department of Internal Medicine/Hematooncology, Masaryk University, Brno, ***Department of Nuclear Medicine, Olomouc Teaching Hospital, Olomouc, ****Center of Biostatistics and Analyses, Masaryk University, Brno, Czech Republic). Autologous transplantation of mononuclear bone marrow cells in patients with chronic myocardial infarction. Cor Vasa 2007;49(2):46-54.
\end{abstract}

Aim: The aim of this study was to evaluate the efficacy and safety of intracoronary autologous mononuclear bone marrow (MBM) cell transplantation in patients with chronic myocardial infarction (MI).

Methods: Of the first 31 patients treated with intracoronary autologous MBM cell transplantation in the acute phase of MI, 13 exhibited functional improvement (but not normalization of wall motion) at a 3-month follow-up visit and agreed with repeat cell transplantation. They were randomized to either repeat MBM cell transplantation $(n=7)$ or to a 3-month control group $(\mathrm{n}=6)$.

Results: Three adverse effects occurred in association with repeat cell transplantation. Two of these were immediately related to repeat balloon dislocation on a smooth surface of the stent covered with intimal proliferation forming an insignificant restenosis. These dislocations occurred during repeat balloon inflations in the course of cell implantation and resulted in intimal dissection and myocardial damage. The third patient was found to have an isolated increase in troponin I following the procedure. Six-month follow-up results revealed no improvement in myocardial function and perfusion in the infarcted area. Frequent procedure-related side effects and no obvious benefit of cell transplantation resulted in premature termination of the study.

Conclusion: Repeat intracoronary autologous MBM cell transplantation in patients with chronic MI may be associated with relatively frequent procedure-related side effects and does not seem to provide any obvious benefit to the patients. Key words: Cell transplantation - Myocardial infarction - Stem cells

Jaroslav Meluzín, Stanislav Janoušek*, Jiří Mayer**, Ladislav Groch, Jan Sitar, Miloslav Tejc, Petr Kala*, Roman Panovský, Milan Kamínek***, Martin Klabusay***, Zdeněk Kořístek***, Ladislav Dušek**** (I. interní-kardioangiologická klinika, Fakultní nemocnice u sv. Anny, *Interní a kardiologická klinika, **Interní-hematoonkologická klinika, Masarykova univerzita, Brno, ***Oddělení nukleární medicíny, Fakultní nemocnice Olomouc, Olomouc, ****Centrum biostatiky a analýz, Masarykova univerzita, Brno, Česká republika). Autologni transplantace mononukleárních buněk kostní dřeně u nemocných s chronickým infarktem myokardu. Cor Vasa 2007;49(2):46-54.

Cîl: Cílem práce bylo posoudit účinnost a bezpečnost intrakoronárního podání autologních mononukleárních buněk kostní dřeně (MBKD) u nemocných s chronickým infarktem myokardu (IM).

Metodika: Z celkem 31 nemocných léčených intrakoronárním podáním autologních MBKD v akutní fázi IM jich 13 vykazovalo funkční zlepšení (ale nikoliv normalizaci hybnosti stěn) při kontrolním vyšetření ve třetím měsící po IM a souhlasilo s opakovanou transplantací MBKD. Tito nemocní byli randomizováni bud' k opakované transplantaci MBKD $(\mathrm{n}=7$ ) či do tř́iměsíční kontrolní skupiny $(n=6)$.

Výsledky: V souvislosti s opakovanou intrakoronární transplantací MBKD se objevily 3 komplikace. Dvě z nich bezprostředně souvisely s opakovanými dislokacemi katetrového balonku na hladkém povrchu stentu, krytého intimální proliferací, která vedla k nevýznamné restenóze ve stentu. Tyto dislokace balonku se objevovaly během opakovaných insuflaci

*The work was supported in part by a grant of the Ministry of Health of the Czech Republic (IGA, No. 1A/8676-3) and by a grant of the Ministry of Education of the Czech Republic (MSM, No. 0021622402). 
balonku v průběhu intrakoronární implantace buněk a vedly k disekci na povrchu intimy a ke vzniku IM. U třetího nemocného byl nalezen izolovaný vzestup troponinu I po implantaci buněk. Kontrolní výsledky v šestém měsíci sledování neprokázaly žádné zlepšení funkce či perfuze v oblasti IM. Časté komplikace v souvislosti s intrakoronární implantací buněk a chybění zlepšení funkce či perfuze po léčbě byly příčinou předčasného ukončení studie.

Závěr: Opakované intrakoronární podání autologních MBKD u nemocných s chronickým IM může být spojeno s relativně častými komplikacemi a nevede ke zlepšení nemocných.

Kličová slova: Buněčná transplantace - Infarkt myokardu - Kmenové buňky

Address: Prof. Jaroslav Meluzín, MD, FESC, 1st. Dept. of Internal Medicine/Cardioangiology, St. Anna Hospital, Pekařská 53, 65691 Brno, Czech Republic, e-mail: jaroslav.meluzin@fnusa.cz

\section{INTRODUCTION}

At present, the most common cause of congestive heart failure is ischemic heart disease. ${ }^{(1)}$ Among patiens with heart failure due to ischemic heart disease, approximately $2 / 3$ suffered a myocardial infarction. ${ }^{(1)}$ Although coronary angioplasty leads to rapid opening of an acutely occluded coronary artery and myocardial salvage, a large proportion of patients with acute myocardial infarction (MI) survives with a significant functional limitation due to irreversible myocardial damage. In these patients, regeneration of the damaged myocardium using stem cell transplantation represents a significant hope for the future. The first clinical studies utilizing intracoronary autologous transplantation of mononuclear bone marrow (MBM) cells or their subpopulations gave promising results. A majority of them demonstrated significant improvement in myocardial function or perfusion, and a reduction of infarct size. ${ }^{(2-9)}$ Only few reports found only partial or no benefit of cell transplantation. ${ }^{(10,11)}$ However, the promising results of cell therapy in patients with acute MI cannot be automatically extrapolated to patients with left ventricular (LV) dysfunction due to chronic MI, because the conditions for the homing of implanted cells and for their local effect in the area of chronic MI are different from those in acute MI. To date, only few data are available on the effect and safety of intracoronary autologous MBM cell transplantation in patients with myocardial dysfunction due to chronic MI. ${ }^{(12)}$ Moreover, it is not clear yet whether patients responding well to transplant therapy in the acute phase of M will respond again to repeat cell implantation in the chronic phase of MI. Thus, the aim of this study was to analyze the effect and safety of autologous MBM cells transplantation on regional and global LV function and myocardial perfusion of the infarcted area at 3 months after acute MI. For this reason, only patients responding well to cell therapy applied in the acute phase of MI were included.

\section{MATERIALS AND METHOD}

\section{Study population}

This study was an extension of our previous 3-month project studying the effect of the cell dose on myocardial function and perfusion in patients with acute MI treated with autologous MBM cell transplantation. ${ }^{(13)}$ This project included patients with a first acute ST-elevation MI successfully treated by coronary angioplasty with stent implantation (resultant TIMI flow grade 3 ). The patients had to have a significant increase in cardiac enzymes: creatine kinase
(CK) over $20 \mu \mathrm{kat} / \mathrm{L}$ or CK-MB over $3 \mu \mathrm{kat} / \mathrm{L}$ or troponin I over $20 \mu \mathrm{g} / \mathrm{L}$ (normal upper limits in our laboratories are $2.85 \mu \mathrm{kat} / \mathrm{L}, 0.42 \mu \mathrm{kat} / \mathrm{L}$, and $2.0 \mu \mathrm{g} / \mathrm{L}$, respectively) and evidence of irreversible damage of at least 2 akinetic or dyskinetic myocardial segments, as identified by dobutamine echocardiography (DE) and confirmed minimally by rest gated technetium99m sestamibi (MIBI) single photon emission computed tomography (SPECT). In patients who underwent positron emission tomography (PET, 88\% of patients), the PET evidence of nonviability of the infarcted myocardium was also required. Only clinically stable patients below 70 years of age were included. The patients were initially randomized in a $1: 1: 1$ ratio into 3 arms: 1, a treatment group (autologous MBM cell transplantation) treated with a lower dose of cells, 2, a treatment group treated with a higher dose of cells and 3, a control group without the cell transplantation therapy. The lower dose was defined as a mean number of $1 \times 10^{7}$ cells (range $9 \times 10^{6}-2 \times 10^{7}$ ) and the higher dose as a mean number of $1 \times 10^{8}$ cells (range $9 \times 10^{7}-2 \times 10^{8}$ ). The study was approved by the institutional ethics committee and written informed consent was obtained from each patient. The analysis of the 3-month results in a cohort of 66 patients is the topic of another paper. This study includes 13 patients meeting the following new 3-month inclusion criteria: (1) they were successfully treated with initial autologous MBM cell transplantation within 5-9 days of acute MI, (2) they completed both baseline pretransplant and 3-month follow-up investigations, (3) they exhibited functional improvement at 3-month follow-up echocardiography (an increase in the peak velocity of longitudinal contraction of the infarcted wall of at least 10\% and/or improvement in wall thickening to hypo- or normokinesis of at least one originally akinetic nonviable segment), while myocardial dysfunction (at least hypokinesis) in the infarcted area still persisted, (4) the patients agreed with a repeat autologous MBM cell transplantation at 3 months after MI. They were 12 men and 1 women, with a mean age of 54 years (32-65 years). The mean LV ejection fraction was $42 \%$ (23\%-57\%). Two patients had diabetes mellitus, 3 suffered from hypertension, and 7 were treated for hyperlipidemia. The patients were randomized to repeat autologous MBM cell transplantation at 3 months (Group A) or to a 3-month control group (Group B). In patients randomized to repeat cell transplantation, only the higher cell dose was transplanted. The study extension was approved by the institutional ethics committee and new written informed consent was obtained from each patient. The investigation conforms with the principles outlined in the Declaration of Helsinki. 


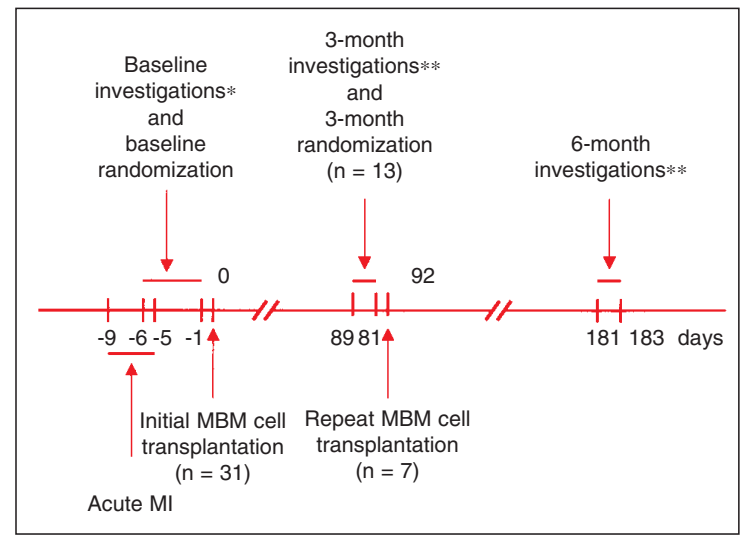

Figure 1 Study design

*Standard echocardiography, Doppler tissue imaging, dobu tamine echocardiography, single photon emission computed tomography, positron emission tomography, coronary angiography; **standard echocardiography, Doppler tissue imaging, single photon emission computed tomography, positron emission tomography, coronary angiography.

MBM - mononuclear bone marrow; MI - myocardial infarction

\section{Study design and the timing of investigations}

The study design is shown in Figure 1. Standard echocardiography, color Doppler tissue imaging, and dobutamine echocardiography $(\mathrm{DE})$ were performed in this sequence on days 3-6 after acute MI. On the following 2-3 days, rest gated MIBI SPECT, PET and, subsequently, bone marrow aspiration were performed. Twenty- to twenty-one hours after the bone marrow aspiration, autologous MBM cell transplantation was performed. The electrocardiograms and blood samples for cardiac enzymes (CK, CK-MB, troponin I) were obtained before and approximately 20 hours after cell transplantation in uncomplicated procedures. The patients were monitored for 24 hours after cell transplantation and discharged two days later. Standard echocardiography, Doppler tissue imaging, gated MIBI SPECT, PET, and coronary angiography were repeated at 3 and 6 months after baseline investigations. In patients randomized to repeat MBM cell transplantation at 3 months, the methods of bone marrow aspiration, MBM cell transplantation, and post-transplant control investigations did not differ from those used in the acute phase of MI. The initial and 3-month control groups of patients underwent examinations and procedures identical to those used in the transplanted patients except for bone marrow aspiration and MBM cell transplantation.

\section{Bone marrow harvesting, processing, and flow cytometry}

The target volume of bone marrow blood $(100 \mathrm{~m}$ for the lower cell dose, $150 \mathrm{ml}$ for the higher cell dose) was obtained from the iliac crest under analgesia, mixed with $4 \%$ human albumin and 5000 IU of heparin, and centrifuged ( $15 \mathrm{~min}, 240 \mathrm{~g}$ ) to receive buffycoat. Mononuclear cells were collected using density gradient centrifugation of the buffy-coat $(20 \mathrm{~min}, 1$ 200 g, Histopaque 1 077, Sigma-Aldrich, St. Louis, MO, USA), washed, and resuspended. $125 \%$ of the target count of mononuclear cells was added to the CellGro serum-free medium (CellGenix, Freiburg, Germany) to reach $0.3-1.0 \times 10^{6}$ cells $/ \mathrm{ml}$. After overnight cultivation $\left(37{ }^{\circ} \mathrm{C}, 5 \% \mathrm{CO}_{2}\right)$ in a Teflon bag (VueLife, CellGenix, Freiburg, Germany), 105\% of the target count of mononuclear cells was withdrawn, washed, and resuspended in Hanks' salt solution (Sigma-Aldrich, St. Louis, MO, USA) with $4 \%$ human albumin and 1000 IU of heparin into a total volume of $22 \mathrm{ml}$. Samples of mononuclear cells were analyzed by flow cytometry on an F500 Cytomics flow cytometer (Beckman Coulter, Fullerton, CA, USA). All samples were incubated with a combination of appropriate monoclonal antibodies directly labeled with fluorochromes FITC, R-phycoerythrin (R-PE) and $\mathrm{PE}-\mathrm{Cy}$ 5. Multicolor analysis was performed using monoclonal antibodies anti-CD45, CD3, CD16, CD19, CD33, and CD34 (Caltag Laboratories, Burlingame, CA, USA). Average values (as the $\%$ of positive cells from the CD45+ population) for T-lymphocytes (CD3), B-lymphocytes (CD19), NK-cells (CD16), myeloid progenitor cells (CD33), and hematopoietic stem cells (CD34) are given in the results.

\section{Implantation of MBM cells into the myocardium}

Autologous MBM cells were transplanted via a percutaneous transluminal catheter using the method described by Strauer et al. ${ }^{(2)}$ To minimize the risk of thrombotic complications, all patients were on daily doses of $100 \mathrm{mg}$ of aspirin and $75 \mathrm{mg}$ of clopidogrel and, in addition, a bolus of 100 units $/ \mathrm{kg}$ of body weight of heparin was administered immediately before the procedure. A total of seven balloon inflations at the site of previous stent implantation lasting for three minutes were carried out. Individual inflations were separated by three-minute intervals of balloon deflation. At the onset of each balloon inflation, $3 \mathrm{ml}$ of MBM cell suspension was slowly injected into the infarct-related artery distal to the site of previous occlusion. This procedure was performed 5 to 9 days after the onset of MI and at 3 months follow-up.

\section{Echocardiography}

Echocardiographic examinations were performed in one center using a Vivid 7 system (GE/Vingmed, Milwaukee, Wisconsin, USA) with an M3S transducer. Two-dimensional and color Doppler tissue images of apical views (apical long axis, apical 4- and 2 -chamber views) were obtained and stored digitally for subsequent offline quantitative analysis using a software incorporated in the Vivid 7 system (Echopac 7 version 1.3, GE/Vingmed). The wider-angle sector (60-70 degrees) was used to depict two-dimensional images for wall motion analysis. The narrow-angle sector (30-45 degrees) was used to obtain color Doppler tissue images of individual (septum, lateral, inferior, anterior, posterior, and anteroseptal) LV walls at high frame rates of 172-234 frames per second. The peak systolic velocities (S) were determined for the basal myocardium of each wall adjacent to the mitral annulus reflecting the regional longitudinal systolic function of individual walls $\left(\mathrm{S}_{\text {septal }}, \mathrm{S}_{\text {lateral }}\right.$, $\mathrm{S}_{\text {inferior }}, \mathrm{S}_{\text {anterior }}, \mathrm{S}_{\text {posterior }}$, and $\left.\mathrm{S}_{\text {anteroseptal }}\right)$. The results were obtained as a mean from 3 consecutive heart cycles. In addition, to determine the global LV 
systolic longitudinal function, six-site mean systolic velocity was calculated as: mean 6 -site $\mathrm{S}=\left(\mathrm{S}_{\text {septal }}+\right.$ $\mathrm{S}_{\text {lateral }}+\mathrm{S}_{\text {inferior }}+\mathrm{S}_{\text {anterior }}+\mathrm{S}_{\text {posterior }}+\mathrm{S}_{\text {anteroseptal }} / 6$. All the analyses were performed by two experienced echocardiographers who were blinded to the patient treatment. The reproducibility of estimation of $\mathrm{S}$ values of individual walls was evaluated in our initial 3-month project. For all $\mathrm{S}$ values, the estimated 95\% confidence limits for differences between intraobserver $(\mathrm{JM})$ pairs of measurement revealed repeated results to vary in a range of $\pm 10.6 \%$ as based on the mean primary values and, similarly, $\pm 11.5 \%$ for interobserver variability (JM and RP).

Dobutamine echocardiography. Dobutamine was administered with an infusion pump at doses of 5 , 10 , and $20 \mu \mathrm{g} / \mathrm{kg} / \mathrm{min}$, each for 5 minutes. The parasternal long axis and three apical views were stored digitally at rest and at the last minute of all doses of dobutamine for a subsequent wall motion analysis. The regional wall motion analysis was performed using a 16-segment model. ${ }^{(14)}$ The akinetic and dyskinetic segments with no improvement in thickening after any dose of dobutamine were regarded as irreversibly damaged. Good interobserver and intraobserver variability in scoring dysfunctional segments (agreement in 93\% and 96\%, respectively) and in determining the contractile reserve (agreement in $92 \%$ and $95 \%$, respectively) has already been described. $^{(15)}$

\section{Gated MIBI SPECT}

Seven hundred and forty $\mathrm{MBq}$ technetium-99m sestamibi (MIBI) was injected at rest. Gated SPECT imaging acquisition (64 projections from the $45^{\circ}$ right anterior oblique projection to the $45^{\circ}$ left posterior oblique projection) began 1 hour after MIBI injection using a 2-detector gamma camera (ecam, Siemens, Erlangen, Germany) equipped with a low-energy, highresolution parallel-hole collimator. MIBI uptake was analyzed visually and quantitatively on computergenerated polar maps by an experienced nuclear cardiologist who was unaware of the patients' treatment. Pixels with a MIBI activity $>2.5$ SD below the corresponding normal mean values were considered abnormal. A perfusion defect was automatically expressed by the computer as the number of abnormal pixels divided by the total number of LV pixels $\times 100 .^{(16)}$ In the viability analysis, the myocardial region with maximum MIBI uptake was used as the reference region. Tracer uptake in other myocardial regions was then expressed as the percent of the activity measured in the reference region. A nonviable myocardium was defined as one showing MIBI uptake below the threshold of $50 \%$ of the maximum.(17) Gated SPECT rest LV ejection fractions and LV enddiastolic/endsystolic volumes were obtained using automated, commercially available 4D-MSPECT software (University of Michigan, Ann Arbor, MI, USA).

\section{Positron emission tomography (PET)}

To assess myocardial viability, F-18-fluorodeoxyglucose-PET was performed with a whole-body PET scanner (ECAT ACCEL, Siemens, USA). Acquisition was started 50 minutes after the administration of fluorodeoxyglucose (200-250 MBq intravenously) and images of glucose utilization were acquired for $15-20$

Table I

Characteristics of the study population

\begin{tabular}{|c|c|c|}
\hline Parameter & Group A (n = 6) & Group B $(\mathrm{n}=6)$ \\
\hline Age (years) & 48 (5) & 58 (3) \\
\hline Males & 5 (83\%) & 6 (100\%) \\
\hline Hypertension & $0 \quad(0 \%)$ & 2 (33\%) \\
\hline Hyperlipidemia & $2(33 \%)$ & $4 \quad(66 \%)$ \\
\hline Diabetes mellitus & $1 \quad(17 \%)$ & $1 \quad(17 \%)$ \\
\hline Single vessel disease & $5 \quad(83 \%)$ & 3 (50\%) \\
\hline Double vessel disease & $1 \quad(17 \%)$ & $3 \quad(50 \%)$ \\
\hline Triple vessel disease & $0 \quad(0 \%)$ & $0 \quad(0 \%)$ \\
\hline IRA: LAD & $6(100 \%)$ & $4 \quad(66 \%)$ \\
\hline IRA: LCX & $0 \quad(0 \%)$ & $1 \quad(17 \%)$ \\
\hline IRA: RCA & $0 \quad(0 \%)$ & $1 \quad(17 \%)$ \\
\hline Maximum CK ( $\mu \mathrm{kat} / \mathrm{L})$ & $60.2 \quad(7.5)$ & 69.9 (10.5) \\
\hline Maximum CK-MB ( $\mu$ kat/L) & $6.5(0.4)$ & $5.6(1.1)$ \\
\hline \multicolumn{3}{|l|}{ Time from infarct onset to reperfusion (min) } \\
\hline - all patients & $650 \quad(446)$ & $230(40)$ \\
\hline - patients treated with primary angioplasty* & 204 (19) & $230 \quad(40)$ \\
\hline \multicolumn{3}{|l|}{ Dobutamine echocardiography } \\
\hline No. of irreversibly damaged segments & $7 \quad(0.6)$ & $6 \quad(1.2)$ \\
\hline No. of stunned segments & $0.2(0.2)$ & $0.7(0.4)$ \\
\hline \multicolumn{3}{|l|}{ Medication } \\
\hline Aspirin & $6(100 \%)$ & $6 \quad(100 \%)$ \\
\hline Clopidogrel & $6(100 \%)$ & $6 \quad(100 \%)$ \\
\hline ACE inhibitor & $6(100 \%)$ & $6 \quad(100 \%)$ \\
\hline Beta-blocker & 6 (100\%) & 6 (100\%) \\
\hline Statin & $6(100 \%)$ & $6 \quad(100 \%)$ \\
\hline
\end{tabular}

The values are expressed as the mean supplied by standard error (in parentheses) or number (\%) of subjects. *Included are only patients treated with coronary angioplasty within 12 hours after symptom onset (Group A, n = 5; Group B, n = 6) .

ACE - angiotensin-converting enzyme; CK - creatine kinase; IRA - infarct-related artery; LAD - left anterior descending coronary artery; LCX - left circumflex artery; No - number; RCA - right coronary artery 
Table II

Comparison of baseline, 3-month and 6-month follow-up echocardiographic and SPECT results for the Group A and B patients

\begin{tabular}{|c|c|c|c|c|c|}
\hline \multirow[t]{2}{*}{ Parameter } & \multirow{2}{*}{$\begin{array}{c}{[\mathrm{B}]} \\
\text { Baseline }\end{array}$} & \multirow{2}{*}{$\begin{array}{c}{[3 \mathrm{M}]} \\
\text { 3-month follow-up }\end{array}$} & \multirow{2}{*}{$\begin{array}{c}{[6 \mathrm{M}]} \\
\text { 6-month follow-up }\end{array}$} & \multicolumn{2}{|c|}{ Pairwise comparison of follow-up values** } \\
\hline & & & & {$[\mathrm{B}]$ vs. $[3 \mathrm{M}]$} & {$[3 \mathrm{M}]$ vs. $[6 \mathrm{M}]$} \\
\hline \multicolumn{6}{|c|}{ Echocardiography } \\
\hline \multicolumn{6}{|c|}{ Mean 6-site S (cm/s) } \\
\hline Group A & $5.1(0.6)$ & $5.7(0.9)$ & $5.3(0.8)$ & $0.6(0.1) \ddagger$ & $-0.4(0.2)$ \\
\hline Group B & $4.9(0.9)$ & $5.9(1.6)$ & $6.0(0.4)$ & $1.0(0.2) \ddagger$ & $0.1(0.4)$ \\
\hline \multicolumn{6}{|c|}{$\mathrm{S}_{\text {infarct }}(\mathrm{cm} / \mathrm{s})$} \\
\hline Group A & $4.6(0.3)$ & $5.2(0.3)$ & $5.4(0.3)$ & $0.6(0.1) \ddagger$ & $0.2(0.5)$ \\
\hline Group B & $3.9(0.4)$ & $5.2(0.6)$ & $5.5(0.5)$ & $1.3(0.3) \ddagger$ & $0.3(0.2)$ \\
\hline \multicolumn{6}{|c|}{ No. of akinetic s.* } \\
\hline Group A & $7.0(0.6)$ & $3.5(0.5)$ & $2.6(0.8)$ & $-3.5(1.0) \doteqdot$ & $-0.9(0.8)$ \\
\hline Group B & $6.2(1.2)$ & $3.5(1.3)$ & $3.2(1.4)$ & $-2.7(1.5)$ & $-0.3(0.3)$ \\
\hline \multicolumn{6}{|l|}{ SPECT } \\
\hline \multicolumn{6}{|l|}{$\operatorname{EDV}(\mathrm{ml})$} \\
\hline Group A & $165(21)$ & $145(15)$ & $146(14)$ & $-20(8) \ddagger$ & $1(4)$ \\
\hline Group B & $127(16)$ & $143(20)$ & $155(21)$ & $16(22)$ & $12(6)$ \\
\hline \multicolumn{6}{|l|}{$\operatorname{ESV}(\mathrm{ml})$} \\
\hline Group A & $101(15)$ & $77(12)$ & $78(10)$ & $-24(8) \ddagger$ & $1(2)$ \\
\hline Group B & 75 (13) & $73(16)$ & $87(20)$ & $-2(2)$ & $14(5) \ddagger$ \\
\hline \multicolumn{6}{|l|}{ LV EF (\%) } \\
\hline Group A & $40(5)$ & $48(5)$ & $47(4)$ & $8(6)$ & $-1(2)$ \\
\hline Group B & $43(4)$ & $50(4)$ & $46(5)$ & 7 (5) & $-4(1) \ddagger$ \\
\hline \multicolumn{6}{|c|}{ Perfusion defect (\%) } \\
\hline Group A & $47(2)$ & $32(5)$ & $34(5)$ & $-15(3) \ddagger$ & $2(2)$ \\
\hline Group B & $44(9)$ & $30(9)$ & 27 (10) & $-14(4) \neq$ & $-3(3)$ \\
\hline
\end{tabular}

The values are expressed as the mean supplied by standard error (in parentheses). *Identified as nonviable on pretransplant dobutamine echocardiography. **Pairwise calculated changes supplied with standard error of the difference. ‡Significant "within group" change of values tested by t-test for two paired samples $(p<0.05)$.

EDV - enddiastolic volume; ESV - endsystolic volume; LV EF - left ventricular ejection fraction; No - number; S - peak systolic velocity of basal myocardium adjacent to mitral annulus; $S_{\text {infarct }}-$ peak systolic velocity of the infarcted wall; $s$ - segments; SPECT - single photon emission computed tomography

minutes in 3D mode. Metabolic defects were analyzed on computer-generated polar maps. The myocardial fluorodeoxyglucose uptake for each part of the left ventricle was adjusted to the myocardial region with maximum fluorodeoxyglucose uptake. A nonviable myocardium was defined as one showing less than $50 \%$ of the maximum fluorodeoxyglucose uptake. ${ }^{(18)}$

\section{Statistical analysis}

The primary endpoint was the change in regional systolic function of the infarcted wall $\left(\mathrm{S}_{\text {infaret }}\right)$. Secondary endpoints were changes in LV ejection fraction, LV volumes, and perfusion defect size. Standard descriptive statistics were used to summarize the sample distribution of individual variables (means, standard errors, confidence limits). A univariate $t$-test for two independent samples was used to compare the values of parameters between Groups A and B. Within the individual groups, comparisons were performed for baseline vs 3-month follow-up results and for 3-month vs 6 -month follow-up results. A paired $t$-test was applied to compare values before and after the treatment. For all used tests, values with $p<0.05$ were considered significant.

\section{RESULTS}

\section{Study population}

Between November 2003 and April 2005, 49 patients underwent baseline and 3-month follow-up investigations. Sixteen patients were initially treated with the higher cell dose, 15 with the lower cell dose, and 18 patients formed a control group. Of a total number of 31 patients treated with cell transplantation in the acute phase of MI, 13 fulfilled the inclusion criteria for repeat autologous MBM cell transplantation and were analyzed in this project (Figure 1). Seven of them were randomized to repeat cell transplantation (Group A), 6 served as a 3-month control group (Group B). The baseline characteristics of the $12 \mathrm{pa}-$ tients undergoing baseline, 3- and 6-month follow-up investigations are shown in Table I. There were no significant differences between Groups A and B.

\section{Phenotype of transplanted cells}

The 3-month samples were analyzed from all 7 patients. The cell suspensions contained $64 \%$ of CD45- and 36\% CD45+ cells. The CD45+ fraction contained $40.9 \%$ of CD3+ cells, $4.5 \%$ of CD16+ cells, $12.8 \%$ of CD19+ cells, $0.4 \%$ of CD33+ cells, and $0.8 \%$ of CD34+ cells.

\section{Effects of cell transplantation in acute and chronic phase of MI on myocardial function and perfusion}

The baseline and the 3- and 6-month follow-up echocardiographic and SPECT results are given in Table II. In one patient with evident MI due to intimal dissection in the course of repeat 3-month cell transplantation, the 6-month follow-up investigations were not carried out. In 1 Group B patient, problems with gating did not allow to assess LV volumes and 
ejection fraction. The parameters derived from Doppler tissue imaging were not evaluated in 1 Group B patient because of poor quality of velocity curve imaging. In both Group A and B patients, significant improvement in regional systolic function of the infarcted wall $\left(\mathrm{S}_{\text {infarct }}\right)$, in the mean 6 -site $\mathrm{S}$, and in myocardial perfusion was found at 3 months. However, no parameters significantly improved following repeat cell transplantation in the chronic phase of MI at 6 months. There were no significant differences between the results of Group A and Group $B$ patients. The values of $S_{\text {infarct, }}$ global $L V$ ejection fraction, and perfusion defect size in individual Group A patients are shown in Figures 2, 3 and 4, respectively. Following repeat cell transplantation, the perfusion defect size was not improved in any of the treated patients. A borderline improvement (absolute increase by $5 \%$ ) of LV ejection fraction was noted in 1 patient; the other 2 patients exhibited improvement (relative increase $\geq 10 \%$ ) in regional LV systolic function. Complete baseline, 3- and 6-month PET data were obtained in only 4 Group A and in 5 Group $\mathrm{B}$ patients and were not used for the analysis of repeat cell transplantation.

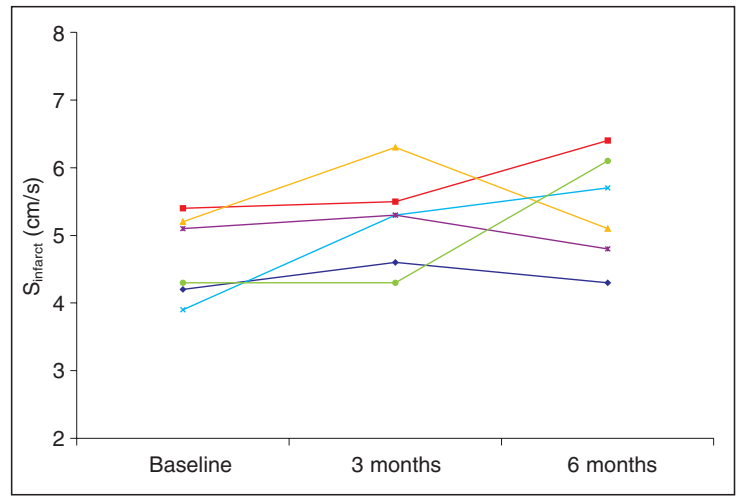

Figure 2 Values of the peak systolic velocity of the longitudinal contraction of the infarcted wall $\left(\mathrm{S}_{\text {infarct }}\right)$ in individual Group A patients.

Only patients with complete baseline, 3-month and 6-month results are presented

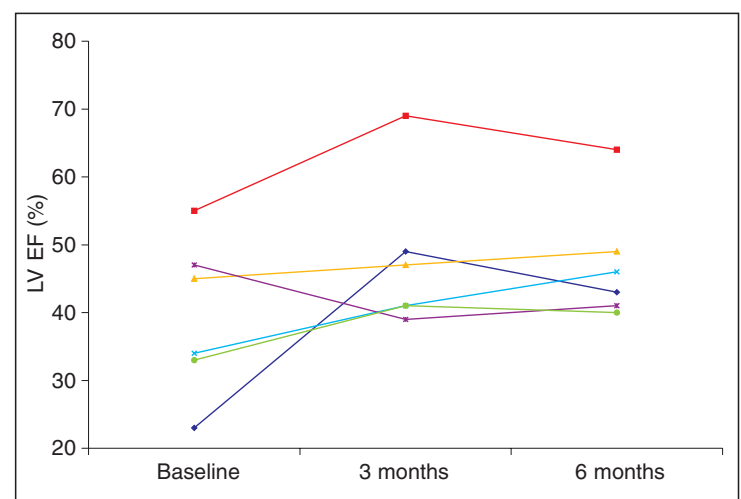

Figure 3 Values of the global left ventricular ejection fraction (LV EF) in individual Group A patients.

Only patients with complete baseline, 3-month and 6-month results are presented

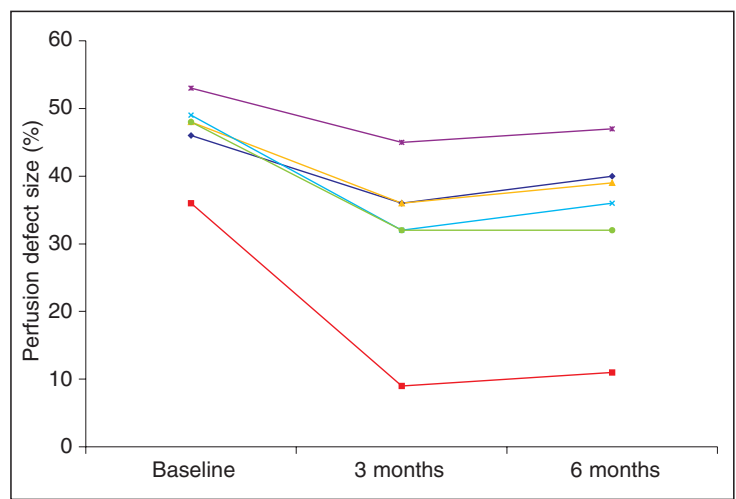

Figure 4 The perfusion defect size in individual Group A patients.

Only patients with complete baseline, 3-month and 6-month results are presented

\section{Safety data}

Three adverse effects occurred in association with repeat autologous MBM cell transplantation at 3 months. Two of them were immediaely related to repeat balloon inflation and catheter manipulation at the site of stent implantation.

Case 1. The first patient developed intimal dissection of the right coronary artery at the site of previous stent implantation resulting in complete vessel occlusion. This complication occurred following the third balloon inflation during cell implantation as a consequence of repeat balloon dislocations on the smooth surfice of the stent covered with intimal proliferation (forming a mild restenosis of approximately $20 \%$ ). The acute vessel occlusion was immediately managed by repeat angioplasty with stent implantation. However, an increase in CK from $2.09 \mu \mathrm{kat} / 1$ to $15.35 \mu \mathrm{kat} / 1$ and CK-MB from $0.23 \mu \mathrm{kat} / 1$ to $1.84 \mu \mathrm{kat} / \mathrm{l}$ clearly indicated a recent MI. The 6-month follow-up investigations were not carried out in this patient.

Case 2. The second patient referred for repeat cell transplantation was found to have a mild in-stent restenosis of the left anterior descending coronary artery $<50 \%$ and $80 \%$ restenosis before the stent which was immediately removed by angioplasty with a good outcome. Subsequently, a full cell dose was implanted. However, the implantation was again associated with problems to stabilize the balloon position at the site of previous stent implantation with an insignificant restenosis. Postprocedural control angiography revealed intimal dissection distal to the stent position with local non-homogeneous vessel filling suggestive of small thrombi. This complication was managed by repeat angioplasty. CK and CK-MB remained within the normal range, but an increase in troponin I three times the normal suggested a minor MI.

Case 3. The third patient was found to have asymptomatic coronary occlusion in the stent at 3 months. The occlusion was resolved by coronary angioplasty, which was immediately followed by repeat cell transplantation without any obvious complications. However, the procedures led to an isolated increase in troponin I (CK and CK-MB remained within the normal range). 


\section{Reasons for premature study termination}

Following analysis of the first 7 patients who underwent repeat autologous MBM cell transplantation at 3-month follow-up, the study was prematurely terminated. Two patients exhibited adverse effects clearly associated with repeat balloon inflations during intracoronary cell implantation. In the third patient, the relation of a minor coronary lesion to repeat cell transplantation is likely. Of the 6 patients transplanted in the chronic phase of MI, who underwent the 6-month follow-up investigation, no significant improvement in myocardial function or perfusion was found, despite the clear benefit of cell transplantation in the acute phase of MI.

\section{DISCUSSION}

The main observation of this randomized study was the lack of any improvement in myocardial perfusion and no obvious functional benefit of autologous MBM cell transplantation in patients with chronic MI, even if all included patients responded well to this therapy applied in the acute phase of MI. In addition, intracoronary cell implantation was associated with serious adverse effects caused by intimal damage in the course of repeat balloon inflations at the site of previous stent implantation. These facts led to premature termination of this project of cell therapy in chronic MI using intracoronary implantation of MBM cells.

Clinical trials on autologous MBM cell transplantation in patients with acute or chronic MI. In patients with acute MI, the majority of studies demonstrated improvement in myocardial function or perfusion and a reduction of infarct size following intracoronary implantation of MBM cells or their subpopulations. ${ }^{(2-9)}$ An incomplete effect (only a reduction of infarct size without any improvement in myocardial function, perfusion, and metabolism) was described by Janssens et al. ${ }^{(1)}$ Only Kuethe et al. ${ }^{(10)}$ did not find any benefit of cell transplantation in a small cohort of patients with a large MI. There were no periprocedural ${ }^{(2,3,6-8,10,11)}$ and rare delayed potentially procedure-related complications, ${ }^{(5)}$ and intracoronary cell implantation using repeat balloon inflations was regarded to be a safe procedure in the treatment of acute MI by the majority of authors. Only Bartunek et al.(9) described an increased incidence of coronary events including in-stent reocclusion or restenosis and de novo stenosis of the infarct-related artery following intracoronary cell transplantation. Concerning patients with chronic MI, there are only few data on the efficiency and safety of intracoronary stem cell implantation. Strauer et al. ${ }^{(12)}$ described, in a nonrandomized study, significant improvement in myocardial function and a reduction of infarct size. There were no periprocedural complications associated with cell implantation. The functional benefit of cell transplantation was also described in two preliminary reports published in abstract form. ${ }^{(19,20)}$ However, except for an Assmus abstract presentation, ${ }^{(20)}$ no data are available on the effect and the safety of repeat intracoronary cell transplantation in the chronic phase of MI, which was applied in our study. Even if no definitive data on transplantation efficiency can be drawn from our study due to the small number of included patients, no improvement in myocardial perfusion and no obvious functional benefit of cell transplantation were observed. In addition, the occurrence of implantation-related side effects resulted in premature termination of the study.

Potential for various results of cell transplantation in the setting of acute or chronic MI. In our study, we did not observe any benefit of cell transplantation in the selected group of patients who responded well to this therapy in the acute phase of MI. In this chapter, we would like to discuss any potential explanations for this finding. In their experiments with rats, $\mathrm{Li}$ et al. ${ }^{(21)}$ demonstrated that the inflammatory response induced by cryoinjury was greatest during the first week. By 2 weeks, the mononuclear infiltrate had almost disappeared, and fibroblasts and collagen deposits were evident. At 4 weeks after cryoinjury, the scar consisted of mature fibrous tissue without lymphocytes. In that study, fetal cardiomyocytes transplanted at 2 weeks reduced scar size and improved myocardial function more effectively than those transplanted at 4 weeks. ${ }^{(21)}$ Sakakibara et al. ${ }^{(22)}$ did not find reversed cardiac remodeling in rats with chronic MI following the fetal cardiomyocyte transplantation. Similarly, no functional benefit or improvement in perfusion following mesenchymal stem cells transplantation 3 months after ligature of the left anterior descending coronary artery was found by Franken et al. ${ }^{(23)}$ In all these studies, the transplanted cells were injected intramyocardially. The effect of intracoronarily given MBM cells may be even more problematic, because the recruitment of stem cells to the scarred tissue in the areas of chronic MI is unclear. Askari et al. ${ }^{(24)}$ demonstrated upregulation of stromal-cell-derived factor 1, a key stem-cell homing factor, immediately after MI and its downregulation within 7 days. Abbott et al. ${ }^{(25)}$ showed that acute MI induces expression of several genes, including those for the vascular endothelial growth factor, matrix metalloproteinase-9, intercellular adhesion molecule-1, and vascular cell adhesion molecule-1 which, along with the stromal cell-derived factor-1, may contribute to bone marrow cell recruitment to the infarcted area. Based on these reports, any significant recruitment of stem cells to scarred tissue in areas of chronic MI seems to be unlikely. In the first human trial studying myocardial engraftment of radioactively labeled MBM cells implanted intracoronarily into the infarct-related artery, no radioactivity was detected in chronically infarcted myocardium, while radioactivity uptake was $4 \%$ in patients with acute MI. ${ }^{(26)}$ Thus, the different homing capacity of intracoronaryly implanted MBM cells may account for the different results of the cell therapy in patients with either acute or chronic MI. In addition, acute MI induces a significant increase in many cytokines (interleukin-6, granulocyte colony-stimulating factor, hepatocyte growth factor, etc) peaking after 24 hours of MI and lowering to baseline on day $7 .^{(27)}$ The lack of contact of implanted cells with mediators of the local acute inflammatory reaction and with various gene expression markers in the infarcted 
area following acute ischemia may diminish the capacity (if present) of implanted cells to contribute to angiogenesis or myocardial regeneration.

\section{Safety considerations}

At present, only few data are available on the safety of intracoronary MBM cell transplantation in patients with chronic IM. Strauer et al. ${ }^{(12)}$ implanted 18 patients with chronic MI (16 received stent) without any procedural or cell-induced complications. In our study, we observed 2 intimal dissections during or immediately following the cell implantation. In contrast to Strauer's study, we implanted cells repeatedly at the site of previous angioplasty with stent implantation, and we used higher pressures (6 atm vs $2-4 \mathrm{~atm}$ in Strauer's study) to inflate the angioplasty balloon during cell implantation. Both our patients with periprocedural intimal dissections had insignificant restenoses at the site of angioplasty at 3 months due to intimal proliferation and, during repeat cell implantations, the cardiologists faced problems with fixing the angioplasty balloon on the smooth surfice of stents covered with intimal proliferation. Complications associated with intracoronary balloon inflations have also been described in patients with idiopathic dilated cardiomyopathy. ${ }^{(26)}$ In our study, the adverse effects along with no benefit of cell implantation resulted in premature termination of the project. Based on our experience, we would like to focus the cardiologists' attention on the potential risk of repeat balloon inflations at the site of previous stent implantation covered with intimal proliferation forming insignificant restenoses.

\section{CONCLUSION}

Repeat intracoronary autologous MBM cell transplantation in patients with chronic MI may be associated with relatively frequent procedure-related side effects and does not seem to provide any obvious benefit to the patients.

\section{Acknowledgements}

The work was supported in part by a grant of the Ministry of Health of the Czech Republic (IGA, No. 1A/8676-3) and by a grant of the Ministry of Education of the Czech Republic (MSM, No. 0021622402). The authors thank Jiři Prášek, MD, and Jaroslav Staníček, MD, for participation in SPECT and PET investigations. The authors also thank Ota Hlinomaz, $\mathrm{MD}$, and Ivan Horñáček, MD, for participation in cardiac catheterizations.

\section{REFERENCES}

1. Cleland JGF, Swedberg K, Follath F, et al. The Euro Heart Failure survey programme - a survey on the quality of care among patients with heart failure in Europe. Eur Heart J 2003;24:442-63.

2. Strauer BE, Brehm M, Zeus T, et al. Repair of infarcted myocardium by autologous intracoronary mononuclear bone marrow cell transplantation in humans. Circulation 2002;106:1913-8.

3. Assmus B, Schachinger V, Teupe C, et al. Transplantation of progenitor cells and regeneration enhancement in acute myocardial infarction (TOPCARE-AMI). Circulation 2002;106:3009-17.

4. Britten MB, Abolmaali ND, Assmus B, et al. Infarct remodeling after intracoronary progenitor cell treatment in patients with acute myocardial infarction (TOPCARE-AMI). Circulation 2003;108:2212-8.

5. Schachinger V, Assmus B, Britten MB, et al. Trans plantation of progenitor cells and regeneration enhancement in acute myocardial infarction. Final one-year results of the TOPCARE-AMI trial. J Am Coll Cardiol 2004;44:1690-9.

6. Wollert KC, Meyer GP, Lotz J, et al. Intracoronary autologous bone-marrow cell transfer after myocardial infarction: the BOOST randomised controlled clinical trial. Lancet 2004;364:141-8.

7. Fernández-Avilés F, Román JAS, García-Frade J, et al. Experimental and clinical regenerative capability of human bone marrow cells after myocardial infarction. Circ Res 2004;95:742-8.

8. Chen S, Fang W, Ye F, et al. Effect on left ventricular function of intracoronary transplantation of autologous bone marrow mesenchymal stem cell in patients with acute myocardial infarction. Am J Cardiol 2004;94:92-5.

9. Bartunek J, Vanderheyden M, Vandekerckhove B, et al. Intracoronary injection of CD133-positive enriched bone marrow progenitor cells promotes cardiac recovery after recent myocardial infarction. Circulation 2005;112 Suppl I:I-178-I-183.

10. Kuethe F, Richartz BM, Sayer HG, et al. Lack of regeneration of myocardium by autologous intracoronary mononuclear bone marrow cell transplantation in humans with large anterior myocardial infarctions. Int J Cardiol 2004;97:123-7.

11. Janssens S, Dubois Ch, Bogaert J, et al. Autologous bone marrow-derived stem-cell transfer in patients with ST-segment elevation myocardial infarction: doubleblind, randomised controlled trial. Lancet 2006;367: 113-21.

12. Strauer BE, Brehm M, Zeus $\mathrm{T}$, et al. Regeneration of human infarcted heart muscle by intracoronary autologous bone marrow cell transplantation in chronic coronary artery disease. The IACT study. J Am Coll Cardiol 2005;46:1651-8.

13. Meluzín J, Groch L, Janoušek S, et al. Autologous transplantation of bone marrow cells in patients with acute myocardial infarction. The effect of the number of transplanted cells on the reduction of infarct size. Eur Heart J 2005;26 Suppl:220 [Abstract].

14. Schiller NB, Shah PM, Crawford M, et al. Recommendations for quantitation of the left ventricle by two-dimensional echocardiography. J Am Soc Echocardiogr 1989; 2:358-67.

15. Meluzín J, Cigarroa CG, Brickner E, et al. Dobutamine echocardiography in predicting improvement in global left ventricular systolic function after coronary bypass or angioplasty in patients with healed myocardial infarcts. Am J Cardiol 1995;76:877-80.

16. Dakik HA, Howell JF, Lawrie GM, et al. Assessment of myocardial viability with $99 \mathrm{mTc}$-sestamibi tomography before coronary bypass graft surgery. Circulation 1997; 96:2892-8.

17. Maes AF, Borgers M, Flameng W, et al. Assessment of myocardial viability in chronic coronary artery disease using technetium-99m sestamibi SPECT. J Am Coll Cardiol 1997;29:62-8.

18. Baer FM, Voth E, Schneider ChA, Theissen P, Schicha H, Sechtem U. Comparison of low-dose dobutaminegradient-echo magnetic resonance imaging and positron emission tomography with (18F) fluorodeoxyglucose in patients with chronic coronary artery disease. Circulation 1995;91:1006-15.

19. Assmus B, Honold J, Schachinger V, et al. Transcoronary transplantation of progenitor cells in patients with 
persistent left ventricular dysfunction after myocardial infarction: a randomized controlled trial (TOPCARE-CHD). Circulation 2005;112 Suppl II:II-632.

20. Assmus, B, Honold J, Fischer-Rasokat U, et al. Intracoronary cell transplantation in patients with chronic myocardial infarction: a randomized intrapatient comparison of bone marrow-versus blood-derived progenitor cells (TOPCARE-Crossover Trial). Circulation 2005; 112: Suppl II:II-582.

21. Li RK, Mickle DAG, Weisel RD, Rao V, Jia ZQ. Optimal time for cardiomyocyte transplantation to maximize myocardial function after left ventricular injury. Ann Thorac Surg 2001;72:1957-63.

22. Sakakibara Y, Tambara K, Lu F, et al. Cardiomyocyte transplantation does not reverse cardiac remodeling in rats with chronic myocardial infarction. Ann Thorac Surg 2002;74:25-30.

23. Franken P, Maskali F, Lahoutte T, et al. Effect of mesenchymal stem cells on myocardial perfusion and func tion in a rat model of chronic infarction. Eur Heart J 2005;26 Suppl:686-7 [Abstract].

24. Askari AT, Unzek S, Popovic ZB, et al. Effect of stromal- -cell-derived factor 1 on stem-cell homing and tissue regeneration in ischaemic cardiomyopathy. Lancet 2003; 362:697-703.

25. Abbott JD, Huang Y, Liu D, Hickey R, Krause DS, Giordano FJ. Stromal cell-derived factor- $1 \alpha$ plays a critical role in stem cell recruitment to the heart after myocardial infarction but is not sufficient to induce homing in the absence of injury. Circulation 2004;110:3300-5.

26. Penicka M, Lang O, Widimsky $P$, et al. Early tissue distribution of bone marrow mononuclear cells after transcoronary transplantation in human. Eur Heart $J$ 2005;26 Suppl:221 [Abstract].

27. Wojakowski W, Tendera M, Michalowska A, et al. Mobilization of CD34/CXCR4+, CD34/CD117+, c-met+ stem cells, and mononuclear cells expressing early cardiac, muscle, and endothelial markers into peripheral blood in patients with acute myocardial infarction. Circulation 2004;110:3213-20.

Received 18 July 2006

Accepted 13 December 2006 